\title{
THE ASEM EDUCATION PROCESS: IMPLICATIONS FOR HIGHER EDUCATION INTERNATIONALISATION IN MALAYSIA
}

\author{
M.Miandy Munusamy* \\ Azirah Hashim \\ Asia-Europe Institute, Universiti Malaya \\ 50603 Kuala Lumpur, Malaysia \\ *Corresponding author: miandy781121@gmail.com
}

\begin{abstract}
The education process of the Asia-Europe Meeting (ASEM) has played an important role in higher education internationalisation since the establishment of ASEM in Bangkok, Thailand in 1996. The ASEM Education Process (AEP) consists of 53 ASEM partners and more than 15 ASEM education stakeholders who meet regularly for discussions on policies and reform measures. There are four priority areas and two transversal themes introduced in the AEP for policy direction and strategy implementation in the field of higher education. Malaysia has participated in the AEP since 2008 and has led and organised various initiatives and meetings on the internationalisation of higher education and global recognition. This study aims to explore the implications of the AEP for the process of internationalisation of higher education in Malaysia. A qualitative study with semi-structured interviews was conducted with fifteen senior officers of the Ministry of Higher Education, Malaysia and five Malaysian research universities. The data were analysed by employing the Qualitative Data Analysis software, the Nvivo version 11, to identify themes and categories. The findings reveal that the AEP can play a major role in internationalising Malaysian higher education through effective networking and strategic alliances. The four priority areas of the AEP has provided opportunities for Malaysia to work closely with European and Asian counterparts in the field of higher education. The findings can assist the Malaysian higher education stakeholder to participate actively in the inter-regional organisation to learn and share best practices and to formulate and revise policies on higher education internationalisation.
\end{abstract}

Keywords: ASEM Education Process, Internationalisation of higher education, Malaysian higher education system, NVivo and Networking

\section{Introduction}

The significance of higher education for local and global development was developed and enhanced through effective initiatives of international, intergovernmental and inter-regional organisations (Shahjahan, 2012). International and intergovernmental organisations such as the United Nations Educational, Scientific and Cultural Organisation, Association of Southeast Asian Nations (ASEAN) and inter-regional organisations such as the Asia-Europe Meeting (ASEM) and the Asia-Pacific Economic Cooperation (APEC) place emphasis on the reform agenda for higher education internationalisation (de Wit, 2020). Among these organisations, 
ASEM and APEC focus more on education and higher education cooperation between nations than the others. However, APEC, created in 1989, is mainly aimed at free trade and economic cooperation (Lee, 2012). Meanwhile, ASEM which was formed in 1996 in Bangkok, Thailand, has since then developed a platform for discussion and cooperation in three important global fields. These are political, economic and socio-cultural including educational matters (Le Thu, 2014). In the international arena, ASEM has been listed as one of the strongest inter-regional cooperation focusing on effective cooperation between Asia and Europe (Khandekar, 2018) among various organisations.

ASEM gives priority to mutual benefits and bridges the gap between Asia and Europe in terms of cooperation in various fields, including higher education (Reiterer, 2009). ASEM facilitates inter-regional cooperation between communities and higher education institutions of Asia and Europe (Lee, 2012), creating a platform to strengthen the higher education internationalisation of ASEM partners. In 2006, a decade since its inception, the education pillar was recognised and the first Education Ministers meeting was held in 2008 to enhance discussion and cooperation in tertiary education. In May 2008, the Federal Ministry of Education and Research, Germany hosted the first ministerial meeting on education (ASEMME1) in Berlin and this marked the birth of the ASEM Education Process (AEP). Since then, the AEP has influenced the development of higher education in Asia and Europe (Dang, 2013) and internationalisation of higher education became the major attention of the AEP. In particular, it has the abilities to guide the development of higher education in the both regions through the agenda-setting process (Dang, 2016).

The impact of globalisation and internationalisation has influenced human capital and talent development in Malaysia, especially through international cooperation (MOE, 2020). The agenda on internationalisation has been prioritised in the Malaysian higher education system after the establishment of a separate Ministry for higher education in 2004. Since then, various strategic plans have been introduced to enhance the quality of higher education, visibility and global recognition through internationalisation. From the beginning 2008, the Ministry of Higher Education, Malaysia (MOHE) has participated in the AEP through Ministerial and stakeholders level meetings and has organised several initiatives at Ministerial and stakeholders levels such as the Fourth ASEM Education Ministers' Meeting (ASEMME4) and the Third ASEM University Business Forum in Kuala Lumpur under the four thematic priorities of the AEP. Although Malaysia has participated in the AEP for the past decade, there appears to not have been tangible outcomes or policy development on international cooperation in the field of higher education. However, a few Asian countries such as Indonesia hosted the ASEM Education Secretariat (AES) from 2013 to 2017. De Wit et al. (2015) stated that Malaysia's active engagement in the ASEM education cooperation since ASEMME1 can be seen to be a positive effort in enriching greater cooperation with Europe and Asia to enhance strategies and to tackle higher education internationalisation matters. Thus, this study aims to explore the implications of the AEP to the process of higher education internationalisation in Malaysia through semi-structured interviews with key personnel. The implications of the AEP is categorised in terms of its functions, contributions and the effects of the four thematic priority areas to Malaysian higher education development and internationalisation.

The article begins with a brief background of the AEP and its rationale for higher education internationalisation. It is then followed by a review of literature on the internationalisation of higher education and the higher education internationalisation process in Malaysia. Next, the research design and methodology employed for this study are described. This is followed by 
the qualitative findings and discussion. Finally, the article presents the conclusion and implication of the study.

\section{The ASEM education and internationalisation}

The creation of ASEM brings a new status to Asia and it shows the recognition of the importance of Asia by Europe (Yeo, 1997). Since the Fourth ASEM Summit (ASEM4), ASEM has started to emphasise the importance of people-to-people contacts and education (Le Thu, 2014). Subsequently, in the Sixth ASEM Summit (ASEM6), ASEM Leaders endorsed a separate ministerial meeting for education (ASEM, 2006). After the first official ministerial meeting on education in 2008, the focus of the AEP was on four thematic priority areas, namely (1) quality assurance and recognition, (2) engaging business and industries in education, (3) balanced mobility and (4) technical and vocational education and training, including lifelong learning (ASEMME3, 2011). The four priorities reflect the common interests of Asia and Europe and are a fixed agenda for senior officials and ministers level meetings. A two pillar system (dialogue and results-oriented initiatives) was endorsed in the fifth ministerial meeting (ASEMME5). This system has increased the visibility of tangible outcomes for the success of higher education in Asia and Europe and for sustainability in the globalised world (AES, 2015). The Conclusions by the Chair is a key ASEM education policy document containing "the ministers' political viewpoints, the common goals, major achievements, new initiatives, and activities" (Dang, 2018a, p. 262). It is a high-level document and adopted as a policy document for the implementation of various endorsed initiatives under the framework of the AEP. ASEMME1 set a pathway for the formation of initiatives under the AEP and encouraged ASEM partners to build a strong partnership to internationalise higher education in order to meet the $21^{\text {st }}$-century challenges (ASEMME1, 2008). As of December 2019, more than fifty initiatives and projects and more than 120 working and expert group meetings at stakeholders' level have been held within Asia and Europe (AES, 2019).

As of $1^{\text {st }}$ January 2020, seven ministerial meetings at the political level were held to shape higher education development in both regions. Although all the meetings emphasised the importance of the four priorities, digitalisation and sustainable development goals were included as two transversal themes to meet the challenges of the Fourth Industrial Revolution (ASEMME7, 2019). The uniqueness of the AEP is the creation of a special rotation secretariat in 2009 to manage higher education collaboration between Asia and Europe (Gaens, 2018). So far, three nations (Germany, Indonesia and Belgium) have hosted the secretariat and the following term should be hosted by an Asian partner (ASEMME7, 2019). The secretariat has to effectively manage and coordinate the networking between ASEM partners and hosting of the political and stakeholders level meetings.

Currently, 53 ASEM partners and more than fifteen International organisations such as the ASEAN University Network (AUN) and the International Association of Universities (IAU) actively discuss, share best practices and identify reform measures through political and stakeholders level meetings (Nagarajan \& Tozsa, 2018). Thus, the rationales of the AEP are to enhance the transparency of different higher education systems and make them more compatible. The AEP's key objective is ensuring the quality and competitiveness of higher education systems and institutions to produce qualified and employable citizens and promoting economic growth in Asia and Europe (AES, 2013). The high priority of the AEP is to bridge the gap between diverse higher education systems through an informal political process of inter-regional cooperation which is supported and implemented by a series of initiatives and 
concrete actions. Through this, the main aim of the AEP is to enhance cooperation and exchanges in higher education between Asia and Europe (AES, 2013).

Malaysia joined ASEM in 1996 and the AEP in 2008. Malaysia has hosted more than twenty ASEM events such as the Third ASEM Culture Ministers' Meeting (2008), the Fourth ASEM Education Ministers' Meeting (2013) and the ASEM Symposium on Countering Radicalisation (2016) (ASEF, 2017). In terms of higher education, Malaysia has been a member of more than ten initiatives and has led the ASEM-AEI Summer School since 2015. Additionally, an officer of MOHE has been seconded to the Secretariat in Jakarta and Belgium to assist and share expertise for the progress of the AEP (ASEMME7, 2019). The participation and involvement of Malaysia in ASEM and the AEP strategically would enhance the political, economic, sociocultural and academic development in Malaysia to internationalise Malaysian higher education. Thus, Gaens (2018) and Dang (2013) stated that the networking outlook of ASEM and in specifically, the AEP can be an exclusive prospect for ASEM partners, including Malaysia to enrich its global prominence in higher education.

\section{The internationalisation of higher education}

International education has developed as an industry. It has become an avenue for income generation and promoting quality education (de Wit, 2020). International education also creates a platform for delivering world-class education (Dumanig \& Symaco, 2020). The rise of globalisation has influenced the higher education sector worldwide to embark on internationalisation to gain international recognition (Dumanig \& Symaco, 2020). Thus, the internationalisation of higher education is seen as a transformation agent in higher education in developed and developing countries around the globe (de Wit, 2020). The understanding on the internationalisation of higher education has focussed to the impact of international and regional cooperation and intercultural and inter-regional capabilities (Morshidi, Samsinar, \& Farhana Tahmida, 2019). The compelling pressure on intensifying internationalisation activities is driven by four key rationales occurring at both the institutional and national levels. These are the socio-cultural, political, economic and academic rationales (de Wit, 2011). However, the recent challenges in higher education internationalisation include the competitiveness in getting international students worldwide and in producing globalised skilled graduates to meet the requirements of industry and business (Robson \& Wihlborg, 2019).

The internationalisation of higher education generally, emphasises the importance of embedding an international dimension in higher education for the benefit of a nation, academics, students and the wider public. However, the recent focus has been on the roles of International Organisations (IOs) and Inter-governmental Organisations in transforming the higher education system around the world (Shahjahan, 2012). Therefore, Knight's (2003) definition of the internationalisation of higher education at the national, higher education sector and institutional levels as the "process of integrating an international, intercultural, or global dimension into the purpose, functions or delivery of postsecondary education" (p. 3) was adopted for this study. The following section looks at the process of higher education internationalisation in Malaysia and the major transitions taking place in the country.

\section{The Malaysian higher education system and internationalisation}

After the British colonial era in Malaya, the higher education system in Malaysia was shifted from the British system to an exclusively Malaysian system (Selvaratnam, 1985) to supply 
human resources for nation growth (Ismail \& Mahani, 2002). The establishment of Universiti Malaya in Kuala Lumpur in 1959 marked the official beginning of the higher education system in Malaysia that has since shaped societal development in Malaysia. However, the development of the Malaysian higher education system has been much affected by the new phenomenon called the "internationalisation of higher education" (Morshidi, 2010). The development of higher education in Malaysia was significantly enhanced after the establishment of MOHE in 2004 (Dobos, 2011). Although MOHE was re-structured under the Ministry of Education, Malaysia several times, it has re-operated again under the Perikatan Nasional government starting March 2020 (BERNAMA, 2020).

The Malaysian higher education system encompasses public and private higher learning institutions. There are 20 government-owned public universities and more than 450 private higher education institutions operating in Malaysia to cater to the needs of local and international students (MOHE, 2018). After three years of establishment of MOHE, in 2007, the first policy document, the National Higher Education Strategic Plan (NHESP) 2007-2020 was introduced. The inauguration of this policy directed the starting point for enhancement of the Malaysian higher education system and the higher learning institutions in Malaysia (Norzaini, Morshidi, \& Abdul Razak, 2014). The transformation of the higher education system through internationalisation for Malaysia to become a higher education hub was embarked on in 2007. Furthermore, Malaysia has the ambition to acquire a leading position as a regional higher education hub in the Southeast Asia region to recruit more international students and talents (Zayed \& Ali, 2015).

Consequently, in 2015, Malaysia introduced a new higher education blueprint to position Malaysia as one of the international higher education hubs in the region with a goal of 250,000 international students by 2025 and to be recognised worldwide (MOE, 2015). The significant shift in the blueprint in this respect is Shift 8: Global prominence which emphasises the internationalisation of Malaysian higher education (Chang Da \& Morshidi, 2017). The key goal is to produce human capital for economic growth (Morshidi et al., 2019). The blueprint aims to position Malaysian universities at the top in the global university rankings to achieve enhanced internationalisation. Furthermore, Malaysian research universities and several private universities have also embarked on internationalisation and implemented strategies to achieve high ranking in the international ranking system (Morshidi et al., 2019). A study conducted by Dumanig \& Symaco (2020) shows that Malaysia is improving research activities and translating higher education policies into vision and mission statement of higher education institutions to champion internationalisation. In a nutshell, the efforts, strategies and plans developed by the Malaysian government encourage higher education institutions to compete in the global market (Abdul Rahman, Farley, \& Moonsamy, 2012) to achieve world-class status to become an international higher education hub in the region (Grapragasem, Krishnan, \& Mansor, 2014).

\section{Data and Methodology}

The sample for this qualitative study was selected through a non-probability sampling by applying the purposive and expert sampling methods (Etikan, Musa, \& Alkassim, 2016). The internationalisation and inter-regional cooperation experts were selected through expert sampling to collect sufficient data. Based on both sampling methods, higher officials of MOHE, including its departments and agencies and Directors of the International Offices of five research universities as well as international experts on internationalisation were interviewed in their respective offices. The number of interviewees and their organisations are 
as shown in Table 1. Eleven male and four female took part in the interviews. The semistructured interviews were conducted by using an interview instrument with contents encompassing international and interregional cooperation, features of the AEP and the internationalisation of higher education. This interview instrument was verified by two internationalisation experts and endorsed by University of Malaya Research Ethics Committee.

Table 1: Number of interviewees and organisation

\begin{tabular}{llccc}
\hline \multirow{2}{*}{ No } & \multicolumn{1}{c}{ Organisation } & $\begin{array}{c}\text { Number of } \\
\text { interviewees }\end{array}$ & \multicolumn{2}{c}{ Gender } \\
\cline { 4 - 6 } & & 3 & 3 & 0 \\
\hline 1 & Ministry of Higher Education & 3 & 2 & 1 \\
2 & Department of Higher Education & 1 & 1 & 0 \\
3 & $\begin{array}{l}\text { Department of Polytechnic Education and } \\
\text { Community Colleges }\end{array}$ & 1 & 1 & 0 \\
4 & Malaysian Qualifications Agency & 1 & 1 & 0 \\
5 & Education Malaysia Global Services & 5 & 2 & 3 \\
7 & International Office-Research University & 1 & 1 & 0 \\
\hline & & $\mathbf{1 5}$ & $\mathbf{1 1}$ & $\mathbf{4}$ \\
\hline
\end{tabular}

Each interview session was held for approximately one to one and a half hours and an audiorecorder and iPhone-6S were used to record the interview sessions. The recording of each interview was transmitted into Qualitative Data Analysis (QDA) software (Nvivo-11) in word format. The volume of data was coded and analysed by concentrating on qualitative content analysis method (Schreier, 2012). The qualitative content analysis method provided an opportunity to conduct explanatory analysis and assisted coding rendering for interpretation, classification and analysis (Kuckartz, 2014). An inductive approach was employed to identify themes and categories and finally, the coding frame was developed according to key elements of the AEP and the internationalisation of higher education. The analysis of the qualitative data through Nvivo 11 software facilitated the production of an exact transcription and allowed the use of direct quotations in the results section (Kuckartz, 2014).

\section{Findings}

The results of the semi-structured interviews show that the impact of the AEP can be seen in six domains in the internationalisation of higher education in Malaysia (Figure 1). These are international and inter-regional cooperation, networks and networking, exchange programmes, industry-academia collaboration, academic qualifications recognition and continuing and professional education. The insights and views of the interviewees are provided in the themes below. 


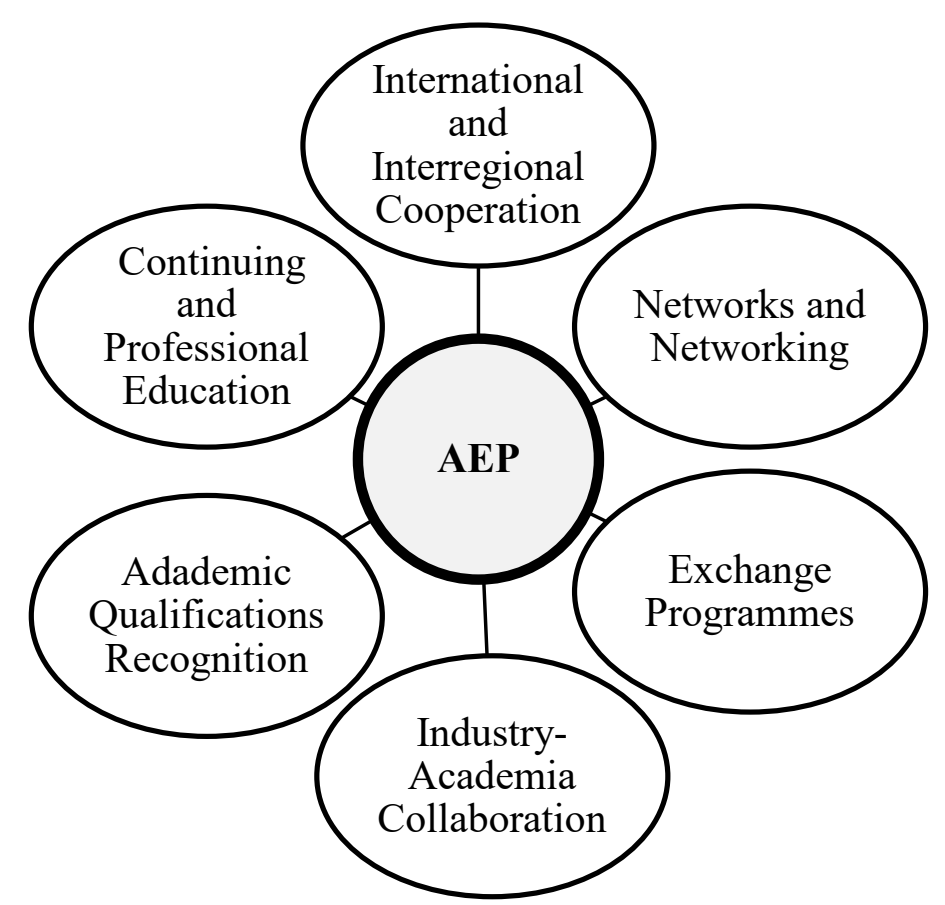

Figure 1: The outcomes of the AEP in the higher education internationalisation in Malaysia

\section{International and interregional cooperation}

The first factor identified was the international and inter-regional cooperation feature of the AEP. Under this theme, interviewees highlighted that the AEP promotes regionalism and strategic alliances. An expert in the area of internationalisation and former Director-General of Department of Higher Education (DHE) stated that "it is interesting to see Asia and Europe coming together to forge an alliance in higher education matters such as student exchanges, the flow of expertise, research collaboration and collaborative projects in higher education". The expert indicated that the strategic alliances through the AEP's political and stakeholders' level meetings offer a venue to meet various stakeholders and policymakers between ASEAN, East Asia and the EU. This is the reason why the AEP is vital for higher education cooperation between two important continents in the world, Asia and Europe. A respondent from one of the research universities in the Klang Valley with more than five years of experience in internationalisation said that "inter-regional cooperation has improved our ability to accept or to interact with people outside ASEAN". Furthermore, strategic alliances by sharing and learning best practices contribute to enhanced collaboration between Malaysia and other ASEM partner countries as stated by two Senior Officers of the departments under MOHE as follows; "Malaysia can work closely with Europe to enhance our higher education system because they have a good system" and "I think it can help to enhance the landscape of higher education system in Malaysia". In this context, a respondent believed that the international cooperation created via the AEP provides an effective platform for Malaysia to recruit more international post-graduate students from Asia and Europe, one of the key pillars to success in higher education internationalisation (Senior Director of DHE). However, a higher official of MOHE recommended that "all stakeholders especially Foreign Affairs Ministry of Malaysia must take initiative and focus more on ASEM" to maintain the effective international and interregional cooperation in higher education through the AEP and as a move to go beyond regional cooperation. 


\section{Networks and networking}

The second theme observed by the interviewees was networks and networking. Interviewees believe that the AEP is the right platform to create more networks in higher education collaboration and would enable Malaysia to interact with networks in Europe and Asia. A respondent from a top research university in Malaysia indicated that "we are a member of 40 networks, active in all networks and the benefits go to staff, lecturers and students and it finally influence the internationalisation". Meanwhile, another respondent from one of the research universities in the north of Malaysia highlights that networks can assist to enhance facilities (infrastructure and lab facilities) for the use of students and faculty members. The networks also assist higher education institutions to achieve community engagement goals. Another important element that makes networks stronger is the credit transfer system. According to a senior officer of an agency under MOHE, the European Union Support to Higher Education in the ASEAN Region (SHARE) is an exemplary project under ASEM platform that strengthens system-to-system integration and facilitates ASEAN Credit Transfer System and ASEAN-EU Credit Transfer System. The interviewees appeared convinced that the credit transfer system within ASEAN, inter ASEAN-EU and among ASEM partners could enhance internationalisation efforts in Malaysian higher education institutions.

Meanwhile, in terms of networking, the AEP motivates exchanges and effective cooperation as well as provides a platform for improvement in understanding of other ASEM partner countries' higher education systems. Networking "brings together leaders, researchers and policymakers within that region to collaborate and exchange ideas to face the challenges of the $21^{\text {st }}$ century" according to a respondent from a top university in Malaysia. "The establishment of branch campuses of European universities in Malaysia shows the learning commitment between the two regions" stated by a senior officer responsible for internationalisation in MOHE. The networking opportunities between the ASEM partners, including Malaysia, enhance inter-university cooperation. A senior administrator of a research university in the southern part of Malaysia indicated that networking becomes a part of internationalisation strategies such as benchmarking, reciprocal research and grant opportunities. The interviewees claimed that interregional cooperation such as the AEP helps the internationalisation of higher education in Malaysian higher education institutions. In supporting this, a senior director in charge for TVET and lifelong learning education said that "the inter-regional cooperation is vital for the creation of relationship and networking. This will help our universities to bit external funding such as from Erasmus + . Besides that, strong networking will enhance the confidence and profile of lectures, staff as well as students". Under this development, a senior officer responsible for international relations opined that ASEM should move from cultural exchanges to academic exchanges so that the ASEM education cooperation can bring greater success in higher education cooperation in both regions which at the end can benefit Malaysian higher education internationalisation.

\section{Exchange programmes}

The movement of staff, students and faculty members from one country to another through various exchange programmes through the AEP becomes a third theme that can improve the internationalisation process in Malaysian higher education. Interviewees highlighted that international cooperation in higher education promotes exchanges such as joint research and short-term and long-term students and staff exchange programmes. A senior officer heading the strategic planning sector of MOHE expressed that the AEP encourages a working together attitude between two regions and mentioned that "Asia-Europe Institute (AEI) is an example, 
how Asia and Europe working together for better future in higher education". AEI has conducted the AEI-ASEM Summer School programme since 2015 as a strategy to overcome mobility imbalance between Asia and Europe. Furthermore, a senior executive officer involved in managing an international student's agency commended the AEP: "we acknowledge the role carried out by the AEP to promote the internationalisation of higher education. Malaysia has signed an MOU with UK-NARIC and has been receiving mobility students from Europe particularly from the United Kingdom, Germany and France”.

Although exchange programmes could promote greater internationalisation, interviewees indicated that there is no clear definition of balanced mobility. An expert on internationalisation said that balanced mobility depends on a comprehensive understanding and an openness to explore other cultures. The expert added that this is a key reason why the balanced mobility indicators in global ranking matrices should be measured wisely to assess its impact on internationalisation. The importance of exchange programmes has been praised by many officers of MOHE and research universities. However, several interviewees have indicated that few higher education institutions in Malaysia are struggling to implement mobility programmes due to lack of funding and challenges in fulfilling the student's choice of destination country. For example, "lots of students coming to Malaysia such as from Thailand and Indonesia, but our students don't want to go there" stated by a senior officer of a research university in the southern part of Malaysia. Likewise, a senior director responsible for internationalisation at the DHE claimed that the regional programme, the ASEAN International Mobility Student Programme (AIMS) is more useful than other inter-regional mobility programmes. Nevertheless, according to an officer of a research university in Klang Valley, mobility programmes are one of the Key Performance Indicators (KPI) of public universities and they need to achieve the KPIs. The interviewees also explained that the private universities in Malaysia do not face any problems in conducting mobility programmes as they have good funding. In summary, an international expert on internationalisation suggested that the AEP initiatives such as the ASEM Work Placement programme and the AEI-ASEM Summer School programme could enhance higher education exchange programmes between ASEM partners, including Malaysia.

\section{Industry-academia collaboration}

The fourth factor indicated was the support of the AEP in facilitating industry-academia collaboration. A senior officer responsible for private higher education management at the DHE stated that Malaysia should focus on this theme to produce skilled graduates required by industry for the nation's growth. This is a new development and a significant priority for Malaysia because "universities no longer providing knowledge but it's linking the knowledge with the skills requested by the industry (international officers of two research universities in Klang Valley). Therefore, more collaboration with industries is needed to achieve the desired graduate employability. The AEP has emphasised the importance of university-business cooperation since 2011, thus an expert on research and planning of MOHE believed that Malaysia can improve collaboration with European countries by sending Malaysian students for internship and placement programmes at the top European multinational companies in Asia and Europe, including Malaysia. In other words, industry-academia collaboration is vital to enhance Malaysia's higher education internationalisation and for the country to become an international hub of higher education in the region. Indeed, the AEP can provide a platform to learn the best practices of European industry-academia collaboration, if not "our higher 
education hub may not survive because everything is related to business" as stated by an expert in higher education internationalisation and former Director-General of DHE.

\section{Academic qualification recognition}

Academic and qualification recognition was observed as the fifth theme that contributes to enhancing the internationalisation of Malaysian higher education. Mutual recognition of academic qualifications between countries is very important for Malaysian graduates to work freely in other countries. Therefore, "we want other countries to accept Malaysian students" as mentioned by a senior officer of the DHE and this can be done by having mutual recognition between Asian and European countries through the AEP initiatives such as the ASEM Bridging Recognition Declaration. Nevertheless, a senior director of an agency under MOHE claimed that currently, mutual recognition is discussed and implemented through bilateral arrangements. Hence, the same director added that "through the AEP network, Malaysia can find other countries in ASEM to work with Malaysian qualifications agency on quality assurance matters". This will ensure Malaysian higher education institutions curriculum are recognised worldwide and achieve global standards. An officer of a top research university also mentioned that their institution has very strict procedures to meet the quality assurance standard.

Thirty European countries are members of ASEM and have harmonised their higher education qualifications recognition by adopting the Bologna Process endorsed in 1999. Although Malaysia is a member of the ASEAN Quality Assurance Network (AQAN), a respondent from a strategic planning division of MOHE said that it is very challenging to harmonise the ASEAN qualifications recognition with Bologna Process because "in ASEAN there are various languages or medium of instruction and different development stages of quality assurance and frameworks, so getting common reference framework is remain big challenges". However, a senior expert of internationalisation believes that the Malaysian Qualifications Agency has reached regional and international standards and it can contribute to the development of qualifications assurance and recognition in other ASEM partner countries. This statement is supported by a senior director of an agency under MOHE who stated that Malaysia has participated in qualifications recognition initiatives under the AEP, namely the ASEM Bridging Recognition Declaration. This initiative provides a platform for Malaysia to learn and share best practices to harmonise higher education qualifications recognition through the AEP.

\section{Continuing and professional education}

The final theme endorsed by interviewees was continuing and professional education. The interview results showed that in terms of Technical and Vocational Education and Training (TVET) and Lifelong Learning (LLL), Malaysia can learn from Europe to develop and to update existing policies on both fields. "Malaysia can work closely with Europe to enhance our higher education system in TVET and LLL because they have a good system" according to a senior director responsible for TVET and LLL at MOHE. Thus, an international expert on internationalisation proposed that Malaysia should work closely with Europe through the AEP to learn best practices of Europe to enhance continuing and professional education in Malaysia. Nevertheless, whatever we learn from Europe "need to cater and mould with local demand and culture" as stressed by a senior officer of the DHE. 
Currently, continuing and professional education is a major focus of polytechnics and community colleges in Malaysia. Therefore, a Director of the International Office of a research university in Klang Valley said that Malaysia needs assistance from IOs to enhance the TVET and LLL studies at universities level. The director added that "in university TVET become very less attractive, so something that the AEP can contribute to the Malaysian higher education system on TVET and LLL". This indicates that the support of the ASEM Education Secretariat is vital to enhance collaboration in the field of TVET and LLL between Asia and Europe, including Malaysia. Furthermore, the Director-General responsible for TVET and LLL at MOHE also underlined the importance of collaboration on continuing and professional education for upskilling and reskilling TVET lecturers in Malaysia. Besides that, MOHE's planning and research division senior officer expressed that the mutual understanding in the AEP can create a pathway for Malaysian students to attend short-term TVET and LLL attachment programmes in Asia and Europe to enhance their skills, knowledge and competence that needed by industry and nations. However, LLL and TVET understanding and cooperation are more easily conducted within regional cooperation as claimed by the same officer.

\section{Discussion}

The nature of ASEM as interregional cooperation, the networking power of ASEM and the four priority themes of the AEP appear to be the key factors that support the internationalisation of Malaysian higher education. Regionalism and strategic alliance were underlined as key elements under the international and inter-regional cooperation that influence Malaysian higher education internationalisation. The significance of regionalism on Malaysian higher education internationalisation efforts through the support of the AEP is in line with the findings of Cabanda, Tan, \& Chou (2019). The findings showed that higher education development in the Asian region was influenced by the development in the West or in particular Europe through effective reflection by Asian countries. Similarly, the interview results revealed that the AEP promotes regionalism through stakeholders and political level meetings such as ASEMMEs and senior officials meetings. Dang (2017) specified that the AEP has created a pathway for the development of higher education regionalism in ASEAN. This has encouraged ASEAN countries, including Malaysia to redesign the landscape of higher education to internationalise and compete with other regions. The strategic alliances can be a driving rationale and an instrument for internationalisation (Knight, 2008) and it also can be a cooperative approach for networking (Teichler, 2009). The strong competition among countries is usually accompanied by strategic alliances with selected partners (Kehm \& Teichler, 2007). Inter-regional cooperation creates a platform for cooperation and collaboration in the field of higher education with other partners in ASEM and with higher education institutions. The close cooperation with other countries will create an avenue to attract more international students to Malaysia (Arokiasamy, 2011) as interviewees stressed that through the AEP, Malaysia can attract more international post-graduate students.

The interviews emphasised the importance of networks and networking. The networks and networking are vital for the internationalisation of higher education in terms of interaction with other countries, research cooperation, exchange of ideas, credit transfer system, establishment of foreign branch campuses and intercultural understanding. The results are in line with the suggestions of Angress \& Wuttig (2018b, 2018a) that networking between ASEM partners will enhance collaboration and strengthen dialogue and cooperation in higher education within the four thematic priorities of the AEP. Girdzijauskaite et al. (2019) reinforced that strong networking between nations around the world can create multi-layered partnerships, including 
the establishment of foreign branch campuses. Recently, in ASEMME7 held in Bucharest, Romania in 2019, the Ministers stressed the pivotal role of networking to enrich the higher education system of ASEM partners through effective cooperation and coordination (ASEMME7, 2019). Networking mostly occurs during the political and stakeholders level meetings. Therefore, the AEP political and the stakeholders' level meetings offer the best opportunities for Malaysian higher education sector to develop networking and gain the internationalisation benefits. The exchange programmes such as staff and student mobility and joint research programmes can enhance Malaysian higher education internationalisation through the support of the AEP. The findings are in line with the MEB (HE) 2015-2025 that states that the importance of expert consultations and professional attachment around the world in enhancing TVET and LLL exchanges through various mobility programmes (MOE, 2015). The Internationalisation Policy for Higher Education that was introduced in 2011 has emphasised staff and students' mobility, academic exchanges and research cooperation to enhance the internationalisation of higher education in Malaysia (MOHE, 2011b). In terms of research collaboration and mobility programmes, a study conducted by Mourato (2019) revealed that collaboration in research, exchange of researchers, staff and students and knowledge transfer has benefited Portuguese social development and economic growth. Thus, a strong collaboration between Malaysia and ASEM partners through the existing AEP initiatives such as the AEI-ASEM Summer School and the ASEF Summer University programmes will most likely benefit Malaysia.

The production of skilled graduates, university curriculum enhancement and internship programme were stressed by interviewees. In the AEP, the ASEM University-Business Forum has been organised since 2010 to develop policies and recommendations to enhance the industry-academia collaboration of ASEM partners (AES, 2019). However, after the fourth forum, it stopped. Malaysia, therefore, has the opportunity to organise the fifth forum to learn best practices from Europe and other Asian partners to produce skilled graduates and to identify strategies for internship programmes. The ASEM Work Placement Programme (AWPP) that was established in 2011 has enhanced graduates skills, capabilities and inter-cultural understanding through an international placement experience. Several higher education institutions in ASEM partner countries have benefited in terms of curriculum development (Angress, 2018). Furthermore, ASEM partners have learned strategies for human capital development and economic growth. Therefore, membership and active participation in the AWPP will assist Malaysia to enhance its industry-academia collaboration.

Mutual recognition on academic qualifications and harmonisation of higher education systems are the major elements of qualifications recognition. The ASEM Education Ministers has made quality assurance and recognition one of the priority themes in 2011. This theme was intended to develop and improve mutual recognition of qualifications and explore the viability of organising the ASEM convention on mutual recognition (ASEMME3, 2011). A study conducted by Shuai \& Lang (2017) proved that many international students chose to study in Malaysia due to the recognition of academic qualifications. Meanwhile, Dang (2018b) revealed that the Asian stakeholders and Ministers were eager to learn and implement the Bologna Process for Asian and ASEAN level cooperation and the concept of Erasmus+ to enhance the cross-border mobility of students. Both elements have been stressed in the AEP since 2008, thus, Malaysia has good prospects to learn the best practices of the Bologna Process to harmonise the higher education system within the Asian and ASEAN region.

TVET and LLL policy enhancement and opportunities to learn from Europe are the key elements emphasised under continuing and professional education. Osborne and Borkowska (2017) specified that the ASEM Education and Research Hub for Lifelong Learning (ASEM 
LLL Hub) has provided information with regards to scholarships and opportunities in LLL research at higher education institutions in ASEM partner countries. Universiti Kebangsaan Malaysia (UKM), since 2009, has been the coordinator of the "Core Competence Network" that undertook research related to human capital competence (ASEM LLL Hub, 2019). Thus, effective coordination between MOHE and UKM and close collaboration with ASEM partners are imperative to develop policies on LLL in Malaysia. The AEP has placed a strong emphasis on TVET and continuing education to enhance its profile in Asia and Europe (Angress \& Wuttig, 2018a). This is vital to meet the skills and knowledge required by employers to meet the challenges of the Fourth Industrial Revolution and it is in line with the aim of Malaysia to make LLL as the third pillar of human capital development in Malaysia (MOHE, 2011a).

\section{Conclusion}

The study explored the impact of the AEP on Malaysian higher education internationalisation by delineating the outcomes resulting from it. The findings underlined the significance of international and interregional cooperation, networks and networking, exchange programmes, industry-academia collaboration, academic qualifications recognition and continuing and professional education that influenced the internationalisation process in Malaysian higher education through the AEP. The findings support the imperative of networking and strategic alliances, close collaboration with ASEM partners to enrich staff and student mobility, recognition of academic qualifications, universities ties with industry and enhancement of TVET and LLL to enhance Malaysian higher education internationalisation. The implications of the study can be applied only to the ministry responsible for higher education and research universities in Malaysia. Thus, for future studies, other public universities in Malaysia can be included and the implications of IOs to Malaysian higher education can be conducted. The results of the study highlight Malaysia's gains through its involvement in the AEP to increase collaboration and enhance the competitiveness of Malaysian higher education. It is hoped that this study has thrown some light on how inter-regional organisations are relevant in assisting the Malaysian national government and higher education stakeholders to learn and share best practices in order to formulate and revise policies on higher education internationalisation effectively.

\section{References}

Abdul Rahman, A., Farley, A., \& Moonsamy, N. (2012). An Examination of the implementation federal government strategic plans in Malaysian Public Universities. International Journal of Business and Social Science, 3(15), 290-301.

AES. (2013). Stocktaking Report of the ASEM Education Process: From Copenhagen to Kuala Lumpur. ASEM Education Secretariat, Bonn. Retrieved from https://www.asemeducation.org/documents/stocktaking-reports/21-stocktaking-report-asemme4-fromcopenhagen-to-kuala-lumpur/file

AES. (2015). Stocktaking Report of the ASEM Education Process: From Kuala Lumpur to Riga. Jakarta, Indonesia: ASEM Education Secretariat Jakarta. Retrieved from https://www.asem-education.org/documents/stocktaking-reports/22-stocktaking-reportasemme5-from-kuala-lumpur-to-riga/file

AES. (2019). ASEM Education Stocktaking Report: From Seoul to Bucharest. Brussels, Belgium: ASEM Education Secretariat, Belgium. Retrieved from https://www.asem- 
education.org/documents/stocktaking-reports/565-stocktaking-report-asemme7-from-seoulto-bucharest/file

Angress, A. (2018). ASEM Education Process in practice: Selected initiatives, programmes and projects. In A. Angress \& S. Wuttig (Eds.), Looking Back and Looking Ahead: The ASEM Education Process - History and Vision (2008-2018) (pp. 99-130). Bonn, Germany: Lemmens Medien GmBh.

Angress, A., \& Wuttig, S. (2018a). ASEM Education Process (AEP) - the road ahead. In A. Angress \& S. Wuttig (Eds.), Looking Back and Looking Ahead: The ASEM Education Process - History and Vision (2008-2018) (pp. 239-246). Bonn, Germany: Lemmens Medien GmBh.

Angress, A., \& Wuttig, S. (2018b). The ASEM Education Process: Vision 2025 - opinions and reflections. In A. Angress \& S. Wuttig (Eds.), Looking Back and Looking Ahead: The ASEM Education Process - History and Vision (2008-2018) (pp. 213-238). Bonn: Lemmens Medien GmBh.

Arokiasamy, A. R. A. (2011). An analysis of globalization and higher education in Malaysia. Australian Journal of Business and Management Research, 1(9), 73-81.

ASEF. (2017). About the Asia-Europe Meeting (ASEM) $\mid$ ASEM InfoBoard. Retrieved October 25, 2017, from http://www.aseminfoboard.org/about

ASEM. (2006). Chairman's Statement of the 6th ASEM Summit. ASEM, Helsinki. Retrieved from https://cdn.aseminfoboard.org/documents/FMM6_ChairStatement_2M0mnSk.pdf

ASEM LLL Hub. (2019). ASEM Education and Research Hub for Lifelong Learning. Retrieved April 1, 2020, from https://asemlllhub.org/

ASEMME1. (2008). Conclusions by the Chair of the ASEMME1. Berlin, Germany. Retrieved from https://www.asem-education.org/documents/senior-official-meetings-andministerial-meetings/asemme1-berlin-2008/29-asemme1-chairs-conclusions/file

ASEMME3. (2011). Conclusions by the Chair of the ASEMME3. Copenhagen, Denmark. Retrieved from https://www.asem-education.org/documents/senior-official-meetings-andministerial-meetings/asemme3-copenhagen-2011/25-asemme3-chairs-conclusions/file

ASEMME7. (2019). Conclusions by the Chair of the ASEMME7. Bucharest, Romania. Retrieved from https://www.asem-education.org/documents/senior-official-meetings-andministerial-meetings/asemme7-bucharest/546-conclusions-by-the-chair-asemme7/file

BERNAMA. (2020). KPT to focus on country's higher education quality. Retrieved March 11, 2020, from https://www.bernama.com/en/general/news.php?id=1819835

Cabanda, E., Tan, E. S., \& Chou, M. H. (2019). Higher education regionalism in Asia: what implications for Europe? European Journal of Higher Education, 9(1), 87-101.

https://doi.org/10.1080/21568235.2018.1561310

Chang Da, W., \& Morshidi, S. (2017). Internationalisation of the Malaysian higher education system through the prism of South-South Cooperation. International Journal of African Higher Education, 4(2), 79-90.

Dang, Q. A. (2013). ASEM - the modern Silk Road: Travelling ideas for education reforms and partnerships between Asia and Europe. Comparative Education, 49(1), 107-119. https://doi.org/10.1080/03050068.2012.740223 
Dang, Q. A. (2016). Shaping an ASEM (higher) education area: Hybrid sectoral regionalism from within. In S. L. Robertson, K. Olds, R. Dale, \& Q. A. Dang (Eds.), Global Regionalisms and Higher Education: Projects, Processes and Politics (pp. 143-165). Cheltenham, United Kingdom: Edward Elgar Publishing Limited. https://doi.org/10.4337/9781784712358

Dang, Q. A. (2017). Regionalising higher education for repositioning Southeast Asia. Oxford Review of Education, 43(4), 417-432. https://doi.org/10.1080/03054985.2017.1327427

Dang, Q. A. (2018a). An anatomy of authority: The Bologna and ASEM education secretariats as policy actors and region builder. Globalisation, Societies and Education, 16(2), 254-267. https://doi.org/10.1080/14767724.2017.1402297

Dang, Q. A. (2018b). The Bologna and ASEM Education Processes: Comparing governance models and outcomes. In A. Angress \& S. Wuttig (Eds.), Looking Back and Looking Ahead: The ASEM Education Process - History and Vision (2008-2018) (pp. 37-46). Bonn, Germany: Lemmens Medien GmBh.

de Wit, H. (2011). Globalisation and internationalisation of higher education. International Journal of Educational Technology in Higher Education, 8(2), 241-248. https://doi.org/10.7238/rusc.v8i2.1247

de Wit, H. (2020). Internationalization of higher education: The need for a more ethical and qualitative approach. Journal of International Students, 10(1), i-iv. https://doi.org/10.32674/jis.v10i1.1893

de Wit, H., Hunter, F., Howard, L., \& Egron-Polak, E. (2015). Internationalisation of higher education (Study). Brussels, Belgium: European Union. https://doi.org/10.2861/6854

Dobos, K. (2011). "Serving two masters" - academics' perspectives on working at an offshore campus in Malaysia. Educational Review, 63(1), 19-35. https://doi.org/10.1080/00131911003748035

Dumanig, F. P., \& Symaco, L. P. (2020). Internationalisation of higher education in Malaysia and the Philippines: A comparative analysis of mission and vision statements of selected universities. Journal of Multilingual and Multicultural Development, 1-13. https://doi.org/10.1080/01434632.2020.1735401

Etikan, I., Musa, S. A., \& Alkassim, R. S. (2016). Comparison of convenience sampling and purposive sampling. American Journal of Theoretical and Applied Statistics, 5(1), 1-4. https://doi.org/10.11648/j.ajtas.20160501.11

Gaens, B. (2018). ASEM: Partnership for greater growth? In B. Gaens \& G. Khandekar (Eds.), Inter-regional relations and the Asia-Europe Meeting (ASEM) (pp. 33-58). London: Palgrave Macmillan.

Girdzijauskaite, E., Radzevičienė, A., \& Jakubavičius, A. (2019). International branch campus: Strategic mapping. In International Scientific Conference: Contemporary Issues in Business, Management and Economic Engineering' 2019. https://doi.org/10.3846/cibmee.2019.045

Grapragasem, S., Krishnan, A., \& Mansor, A. N. (2014). Current trends in Malaysian higher education and the effect on education policy and practice: An overview. International Journal of Higher Education, 3(1), 85-93. https://doi.org/10.5430/ijhe.v3n1p85

Ismail, A. R., \& Mahani, M. (2002). Histrory of the growth and development of higher 
education in Malaysia until 2007. In Z. Moris (Ed.), 50 years of higher education development in Malaysia, 1957-2007 (pp. 1-36). Pulau Pinang, Malaysia: Universiti Sains Malaysia.

Kehm, B. M., \& Teichler, U. (2007). Research on internationalisation in higher education. Journal of Studies in International Education, 11(3-4), 231-239. https://doi.org/10.1177/1028315307303534

Khandekar, R. (2018). ASEM: An asian perspective. In B. Gaens \& G. Khandekar (Eds.), Inter-regional relations and the Asia-Europe Meeting (ASEM) (pp. 209-236). London: Palgrave Macmillan.

Knight, J. (2003). Updating the definition of internationalization. International Higher Education, 33, 2-3. https://doi.org/https://doi.org/10.6017/ihe.2003.33.7391

Kuckartz, U. (2014). Qualitative text analysis: A guide to methods, practice \& using software. London, United Kingdom: SAGE Publications.

Le Thu, H. (2014). Evaluating the cultural cooperation: The role of the Asia-Europe Foundation (ASEF) in the Asia-Europe Meeting (ASEM) process. Asia Europe Journal, 12(4), 401-418. https://doi.org/10.1007/s10308-014-0390-x

Lee, M. N. N. (2012). Regional cooperation in higher education in Asia and the Pacific. Asian Education and Development Studies, 1(1), 18-23. https://doi.org/10.1108/20463161211194432

MOE. (2015). Malaysia Education Blueprint 2015-2025 (Higher Education). Putrajaya: Ministry of Education Malaysia.

MOE. (2020). Way forward for Private Higher Education Institutions: Education as an industry 2020-2025. Putrajaya: Ministry of Education Malaysia. https://doi.org/10.1017/CBO9781107415324.004

MOHE. (2011a). Blueprint on enculturation of lifelong learning for Malaysia 2011-2020. Putrajaya: Ministry of Higher Education Malaysia.

MOHE. (2011b). Internationalisation Policy for Higher Education Malaysia 2011. Putrajaya: Ministry of Higher Education Malaysia. https://doi.org/10.13140/2.1.4424.4162

MOHE. (2018). Kementerian Pendidikan Tinggi Malaysia (MOHE). Retrieved April 3, 2018, from https://www.mohe.gov.my/

Morshidi, S. (2010). Introduction. In Z. Moris (Ed.), 50 years of higher education development in Malaysia, 1957-2007 (p. 202). Pulau Pinang, Malaysia: Universiti Sains Malaysia.

Morshidi, S., Samsinar, M. S., \& Farhana Tahmida, N. (2019). Internationalisation: Dynamics and tension out to 2030. In C. Tully \& S. M. Sidin (Eds.), Rethinking higher education in Malaysia: Strategic foresight addressing critical factor to 2030 (pp. 71-89). Kuala Lumpur: Universiti Tun Abdul Razak (UNIRAZAK).

Mourato, J. (2019). The benefits of internationalization in higher education. The experience in Portuguese Polytechnics. In International Conference on Technics, Technologies and Education ICTTE 2019 (pp. 1-7). https://doi.org/10.15547/ictte.2019.01.104

Nagarajan, L., \& Tozsa, R. (2018). The Asia-Europe Foundation's contribution to the ASEM Education Process: Enhancing mutual understanding through tangible outputs. In A. Agress 
\& S. Wuttig (Eds.), Looking Back and Looking Ahead: The ASEM Education Process History and Vision (2008-2018) (pp. 169-174). Bonn, Germany: Lemmens Medien GmBh.

Norzaini, A., Morshidi, S., \& Abdul Razak, A. (2014). Higher education, learning regions and the Malaysian transformation policies. Higher Education Policy, 27(3), 301-321. https://doi.org/10.1057/hep.2013.26

Osborne, M., \& Borkowska, K. (2017). A European lens upon adult and lifelong learning in Asia. Asia Pacific Education Review, 18(2), 269-280. https://doi.org/10.1007/s12564-0179479-4

Reiterer, M. (2009). Asia-Europe Meeting (ASEM): Fostering a multipolar world order through inter-regional cooperation. Asia Europe Journal, 7(1), 179-196. https://doi.org/10.1007/s10308-008-0210-2

Robson, S., \& Wihlborg, M. (2019). Internationalisation of higher education: Impacts, challenges and future possibilities. European Educational Research Journal, 18(2), 127134. https://doi.org/10.1177/1474904119834779

Schreier, M. (2012). Qualitative Content Analysis in Practices. London, United Kingdom: SAGE Publications.

Selvaratnam, V. (1985). The higher education system in Malaysia: Metropolitan, crossnational, peripheral or national? Higher Education, 14(5), 477-496.

Shahjahan, R. A. (2012). The roles of international organizations (IOs) in globalizing higher education policy. In J. C. Smart \& M. B. Paulsen (Eds.), Higher education: Handbook of theory and research (Vol. 27, pp. 369-407). Dordrecht. Netherlands: Springer. https://doi.org/10.1007/978-94-007-2950-6

Shuai, Z., \& Lang, D. (2017). Factors that influence the international students' decisions to study in Malaysia. Management Science and Engineering, 11(2), 35-38. https://doi.org/10.3968/9802

Teichler, U. (2009). Internationalisation of higher education: European experiences. Asia Pacific Education Review, 10(1), 93-106. https://doi.org/10.1007/s12564-009-9002-7

Yeo, L. H. (1997). The Bangkok ASEM and the future of Asia-Europe relations. Southeast Asian Affairs 1997, 33-45.

Zayed, T. M., \& Ali, H. M. (2015). The internationalization of East Asian higher education: Globalization 's impact. IIUM Journal of Educational Studies, 3(1), 112-119. https://doi.org/10.13140/RG.2.1.2289.2644 